REVIEW

\title{
Proinflammatory potential of the airway epithelium in bronchial asthma
}

\author{
D. Raeburn, S.E. Webber
}

Proinflammatory potential of the airway epithelium in bronchial asthma. D. Raeburn, S.E. Webber. CERS Journals Ltd 1994

ABSTRACT: Histopathological studies of asthmatic airways removed postmortem or by bronchial biopsy show marked inflammatory changes, notably epithelial cell disruption and damage, and the presence of large numbers of eosinophils. The epithelial damage is seen in mild, asymptomatic asthmatics as well as in patients who have died in status asthmaticus. Damage to the epithelium may also correlate with bronchial hyperreactivity.

The epithelium has been suggested to be a target for inflammatory cell mediators and cytokines. Recently, the airway epithelium has itself been shown to produce and release several proinflammatory mediators and cytokines, and to express adhesion molecules for inflammatory cells. The epithelium, thus, may actively participate in the inflammatory changes in asthma, where it may be a source as well as a target.

Drug therapy aimed at preventing inflammatory changes in the epithelium, such as cytokine and adhesion molecule expression, may be an important step forward in halting disease progression in asthma.

Eur Respir J., 1994; 7, 2226-2233.

Rhône-Poulenc Rorer, Ltd, Dagenham Research Centre, Dagenham, Essex, UK.

Correspondence: D. Raeburn

Rhône-Poulenc Rorer, Inc.,

500 Arcola Road

Collegeville

PA 19426

USA

Keywords: Adhesion molecules asthma

cytokines

epithelium

growth factors

inflammation

Received: May 111994

Accepted after revision September 29 1994

\section{Asthmatic inflammation}

Asthma is essentially a chronic inflammatory disease of the airways, in which the prominent clinical symptoms are a reversible airflow obstruction combined with an increased responsiveness to nonspecific stimuli, bronchial hyperreactivity (BHR) [1]. Histopathological studies on tissues taken postmortem [2-4] and, more recently, by bronchial biopsy [5-9], show an inflammatory response with a range of morphological changes not seen in nonasthmatic controls, and which appear to be "typical" of asthma: oedema, mucous cell hyperplasia, smooth muscle hypertrophy, new collagen deposition beneath the epithelial basement membrane, luminal mucus and cellular debris, leucocyte (predominantly eosinophil) infiltration of the bronchial mucosa, and epithelial cell damage and/or sloughing. These inflammatory changes are evident in tissues taken from mild, asymptomatic asthmatics, and from specimens obtained from patients dying during an acute asthmatic episode.

\section{Epithelial cell damage and loss}

Perhaps the most significant finding from the histopathological studies of asthmatic airways is the widespread damage to, or loss of, the epithelium associated with eosinophilic infiltration. The eosinphils are in their activated state and, along with released major basic protein (MBP), are found in areas of epithelial damage [4]. Large numbers of epithelial cells are also found in asthmatic sputum during acute exacerbations [10, 11], whilst bronchoalveolar lavage (BAL) studies [7, 12] indicate that epithelial cells are found in significant numbers in BAL fluid from asthmatics. Furthermore, the epithelium can be shed in clumps of cells with preserved ciliary function, suggesting some defect of adherence to the basement membrane [7]. Thus, sloughing of intact, functional epithelial cells appears characteristic of bronchial asthma.

Some attempt has been made to correlate the degree of epithelial cell loss with the severity of BHR. Significant negative correlation between epithelial cell numbers and BHR was seen in two bronchial biopsy studies [7, 8] but not in others [5, 9]. Similarly, BEASLEY et al. [7] and JEFFREY et al. [12] have demonstrated a significant correlation between epithelial cell numbers in BAL fluid and BHR. Thus, loss of airway epithelial cells may correlate with the degree of airway responsiveness in asthma.

Mechanical removal of the airway epithelium in animal models in vitro generally results in increased reactivity to spasmogens and reduced relaxant effects to bronchodilator substances [13-15]. These effects are probably a combination of the loss of prostanoid (prostaglandin $\mathrm{E}_{2}$, $\left(\mathrm{PGE}_{2}\right)$ ) and nonprostanoid (epithelium-derived relaxant/inhibitory factor, EpDRF/EpDIF) inhibitory factors, loss of metabolic activity (such as neutral endopeptidase), 
and loss of a diffusion barrier. Based on the above findings, a protective role for the epithelium in reducing BHR has been proposed.

\section{Proinflammatory potential of the epithelium}

Asthmatic inflammation is the result of the excessive production and activity of several mediators and cytokines released by inflammatory cells in the airways. The migration of inflammatory cells into the tissues is controlled by adhesion molecules present on the endothelial cells of the blood vessels in the lung. It is believed (see above) that the epithelium is an important target for the action of mediators and cytokines. However, information on the ability of epithelial cells to produce proinflammatory substances and to adhere to inflammatory cells is becoming available, and it is now possible to view the epithelium as an active participant in the cycle of inflammation rather than the innocent target.

\section{Epithelial mediators}

Airway epithelial cells cultured from several species (including human) can generate numerous mediators: leukotrienes $\mathrm{B}_{4}$ and $\mathrm{C}_{4}\left(\mathrm{LTB}_{4}, \mathrm{LTC}_{4}\right)$, prostanoids (prostaglandin $\mathrm{D}_{2}, \mathrm{E}_{2}$ and $\left.\mathrm{F}_{2 \alpha}\left(\mathrm{PGD}_{2}, \mathrm{PGE}_{2}, \mathrm{PGF}_{2 \alpha}\right)\right)$, 5-, 12-, and 15-hydroxyeicosatetraenoic acid (HETEs), 8,15 di-HETE, 12-hydroxyheptadecatrienoic acid (HHT) and platelet-activating factor (PAF) [16-24]. These mediators can be either bronchoconstrictor, proinflammatory or, in some cases, both. The relevance of these findings in vitro to the actions of the epithelium in vivo remains speculative, since it is not known whether these mediators have a physiological role in regulating airway function or indeed if the release of these mediators is increased in asthma. However, agents such as irritant gases, which are thought to be one of the external triggers of asthma, are capable of inducing epithelial cells to release bronchoconstrictor and inflammatory mediators. For example, ozone augments $\mathrm{PGE}_{2}, \mathrm{PGF}_{2 \alpha}$, prostacyclin, $\mathrm{LTB}_{4}, \mathrm{LTC}_{4}, \mathrm{LTD}_{4}$ and $\mathrm{LTE}_{4}, 15-\mathrm{HETE}$ and HHT, and thromboxane $\mathrm{B}_{2}\left(\mathrm{TxB}_{2}\right)$ release from bovine and human tracheal epithelium, whilst $\mathrm{NO}_{2}$ stimulates $\mathrm{PGE}_{2}, 12-$ HETE, 15-HETE and $\mathrm{LTC}_{4}$ production in human bronchial epithelium [23, 25-27]. Exposure to either of these irritant gases produces BHR. Thus, there may be a causative link between irritant gas exposure, release of mediators from the epithelium and airway hyperreactivity.

In addition to the eicosanoids, epithelial cells can also produce endothelin [28, 29], and in asthma its expression is upregulated compared with controls [30]. Endothelin is a potent bronchoconstrictor and can also promote airways smooth muscle proliferation (see below). Thus, it may play a role in the remodelling of the airway wall characteristic of asthma (see later). Substance P and vasopressin are produced by rabbit tracheal epithelium in vivo and in vitro [29]. Substance $\mathrm{P}$ is a potent bronchoconstrictor and also induces microvascular leakage and mucus secretion. Again, however, a role for epithelial cell-derived substance $\mathrm{P}$ in asthma has yet to be established.

\section{Epithelial cytokines/chemokines}

Cytokines are inducible proteins produced by immunologically competent cells (such as lymphocytes and antigen-presenting cells), which have a modulatory role on the cell, including inflammatory cell, function. The proinflammatory properties of cytokines have attracted interest, since they may contribute to asthmatic inflammation [31]. There is now considerable evidence that airway epithelial cells and epithelial cell lines in vitro synthesize and secrete proinflammatory cytokines.

Granulocyte-macrophage colony-stimulating factor (GM-CSF) is produced by the epithelium under basal conditions [24, 32-40], and can be induced by treatment with interleukin (IL)-1 [33, 38, 40] or histamine [38]. Production of GM-CSF by airway epithelial cells appears to be altered during inflammation. Bronchial epithelial cells from asthmatics [34, 37], and nasal epithelium from patients with rhinitis or polyposis [35, 36] produce more GM-CSF than normals. Granulocytecolony stimulating factor (G-CSF) is produced by normal and inflamed nasal epithelium in similar amounts [36], and by human bronchial epithelial cells [39]. Epithelium-derived GM-CSF and G-CSF may have an important role in inflammation in vivo, since, in cell culture, they prolong eosinophil survival [24, 33, 34] with concomitant cell activation (increased production of superoxide and $\mathrm{LTC}_{4}$ ) [34]. Neutrophil survival, likewise, is prolonged by GM-CSF and G-CSF, with evidence of additive effects [39].

The ability of bronchial epithelial cells to produce IL-1 may depend on how they are stimulated. IL-1 was not detectable in human bronchial epithelial cells following lipopolysaccharide (LPS) treatment [41], but was demonstrable in cells exposed to toluene diisocyanate (TDI) [42]. Since air exposure did not stimulate IL-1 production [42], it is unlikely that it is released basally. Recently, exogenously added IL- $1 \beta$ has been shown to inhibit airways smooth muscle contraction by an epithelium-dependent mechanism, possibly due to the release of EpDRF [43]. However, the role of IL-1 in asthmatic airway inflammation and hyperreactivity is not clear.

IL-6 has been demonstrated in human bronchial and nasal epithelium either unstimulated [36, 37, 41], or after exposure to histamine [23], TDI [42], or transforming growth factor- $\beta$ (TGF- $\beta$ ), IL-1 or tumour necrosis factor$\alpha$ (TNF- $\alpha)$ [44]. IL-1 and IL- 6 produced by epithelial cells exposed to TDI increased the number and activation state of presensitized T-cells in co-culture [42]. Basal expression of IL- 8 has been reported in asthmatic but not control bronchial epithelium [37]. However, stimulation with IL-1 produced appreciable levels of IL-8 accompanied by neutrophil chemoattractant activity [45]. IL-6 and IL-8 production, along with GM-CSF, appears to be upregulated in bronchial epithelial cells from symptomatic asthmatics [37]. IL-8 is expressed in human nasal epithelium under basal conditions, and is 
upregulated following respiratory syncitial virus (RSV) infection or treatment with TNF or IL-1 [46]. The upregulation of IL-8 expression in the airway epithelium may be particularly important in the early stages of an inflammatory response (and in respiratory infections), since it is a potent neutrophil chemoattractant. In contrast to other studies [35, 36], BECKER et al. [46] failed to detect GM-CSF, or evidence of IL- 1 or IL-6 production [46]. $\mathrm{NO}_{2}$ treatment augments the release of IL-8, GM-CSF and TNF- $\alpha$ [47].

Macrophage colony stimulating factor (M-CSF), IL-4 and interferon- $\gamma($ IFN- $\gamma$ ) have not been demonstrated in human airways epithelium [36, 47]. However, CHEN et al. [48] reported that IFN- $\gamma$ increased the sensitivity of guinea-pig airways smooth muscle to isoprenaline, but did not affect the maximum contraction. As with IL-1 $\beta$ [43], the effects were epithelium-dependent.

RANTES (regulated on activation, normal T-cells, expressed and secreted) is a chemokine (chemotactic cytokine) which is chemoattractant for monocytes, eosinophils, basophils and T-cells [49]. RANTES is not expressed by the human lung epithelial cell line (A549) under basal conditions [50]. However, stimulation with IL-1 or TNF (but not IL-2, IL-4, IL-6, GM-CSF or IFN$\gamma$ ) induced RANTES messenger ribonucleic acid (mRNA) expression and protein production in a time- and concentration-dependent manner [50]. RANTES, therefore, may have a role in asthmatic inflammation.

Macrophage inflammatory proteins (MIP) $1 \alpha$ and 2 stimulate inflammatory cell recruitment [51]. DRISCOLL et al. [51] have recently demonstrated MIP-2, but not MIP- $1 \alpha$ in rat airway epithelial cells after stimulation with TNF.

There is no information, as yet, on the production of other cytokines, such as IL-5, by airway epithelial cells.

\section{Epithelial adhesion molecules}

Migration of inflammatory cells from the blood stream into the tissues is critical to the genesis of an inflammatory response. Before egress from the blood compartment into the extravascular tissues during inflammation, leucocytes must first adhere to the endothelial cells. This is achieved by the interaction of adhesion molecules expressed on the cell surface of both cell types [52]. The potential role of adhesion molecules in asthmatic inflammation is now of considerable interest [53].

The principal endothelial cell adhesion molecules are intercellular adhesion molecule-1 (ICAM-1), vascular cell adhesion molecule-1 (VCAM-1), endothelial-leucocyte adhesion molecule-1 (ELAM-1), and granule-associated membrane protein-140 (GMP-140). These molecules recognize specific ligands expressed on the cell surface of inflammatory cells, such as granulocytes, monocytes and lymphocytes. During inflammation (or exposure to cytokines, such as TNF, IFN- $\gamma$ or IL-1), adhesion molecule expression on both endothelial and inflammatory cells is upregulated [53]. This increase in adhesion molecule expression presumably leads to enhanced recruitment of inflammatory cells from the vascular compartment into the interstitium, with the subsequent perpetuation of the inflammatory response. In addition, increased expression of adhesion molecules on the epithelium will lead to the recruitment of cells, notably eosinophils, to the epithelial surface, where their degranulation and release of cytotoxic products will further damage the epithelium to maintain the inflammatory changes and, possibly, increase airway reactivity.

In addition to being present on the endothelium, ICAM1 can be expressed under basal conditions by airway epithelial cells in culture and from cells obtained by bronchial biopsy or lavage [54-62]. Greater expression of ICAM-1 was seen in the 9HTEo ${ }^{-}$epithelial cell line than in primary epithelial cell cultures $[54,56]$. The effect of cytokines on ICAM-1 expression is controversial. IFN- $\gamma$ but not TNF- $\alpha$ or IL-1 increased ICAM-1 expression in human tracheal epithelial cells in primary culture and in the BEAS-2B cell line [55], whereas TNF- $\alpha$ and IL1 increased ICAM-1 expression in human tracheal epithelial cells in primary culture and in $9 \mathrm{HTEo}^{-}$cells [54]. ICAM-1 expression was increased in BEAS2-B cells and human bronchial epithelium in primary culture by IFN$\gamma$ and TNF- $\alpha$ [57]. IFN- $\gamma$ also increased ICAM-1 in the NCI-H292 cell line [57]. Parainfluenza virus (PIV) infection increased ICAM-1 expression in human cultured tracheal epithelium [56]. ICAM-1 is constitutively expressed on, and upregulated by, TNF- $\alpha$, IL- 1 and IFN- $\gamma$ in monkey bronchial epithelial cells in culture $[58,59]$. Antigen challenge increased ICAM-1 expression in vivo in the monkey, whilst antigen-induced eosinophil infiltration and BHR were markedly reduced following treatment with a monoclonal antibody to ICAM-1. Epithelial cell expression of ICAM-1 in asthmatics has been compared with controls [60, 61]. The results from the two studies are conflicting. Whilst MONTEForT et al. [60] found no difference in ICAM-1 expression between asthmatic and control epithelium, VIGNOLA et al. [61] demonstrated that ICAM-1 expression was increased in asthmatics, and that it correlated with clinical scores and lung function. Phorbol esters increased ICAM-1 expression in human bronchial epithelial primary cultures [57] and in the NCI-H292 [57, 62] and BEAS2-B cell lines [62]. Allergen exposure increased ICAM-1 expression on conjunctival epithelium [63].

Unlike ICAM-1, ELAM-1 has not been demonstrated on airway epithelial cells [57, 59, 60]. VCAM-1 is present on renal tubular epithelium, where its expression is upregulated by IFN- $\gamma$, TNF- $\alpha$, IL- 1 and phorbol ester [64]. However, neither VCAM-1 nor GMP-140 are expressed or upregulated by cytokines in airway epithelial cells [57].

Neutrophil adherence to airway epithelial cells has been demonstrated in vitro [54-56, 65, 66]. Greater adherence (ten-fold) was seen in the 9HTEo ${ }^{-}$cell line compared with the primary culture cells [54]. The adherence appears to be, at least partly, ICAM-1-dependent [54-56], and increased by IFN- $\gamma$ [56], viral infection [57], phorbol ester, LPS and cigarette smoke [65]. Contrasting data have been presented [66], where TNF$\alpha$ and IL-1 reduced the already low neutrophil adherence to canine tracheal epithelium. IFN- $\gamma$ was without effect. 
Therefore, the epithelium may not be a particularly important site of adherence for neutrophils, which may only need to reach the submucosal layers to cause inflammation. However, eosinophil binding to monkey bronchial epithelial cells is inhibited by a monoclonal antibody to ICAM-1 [58], which suggests an important role of this adhesion molecule in attracting eosinophils to the epithelium.

\section{Epithelial growth factors}

A thickened basement membrane or, more correctly, a sub-basement membrane fibrosis is one of the pathophysiological markers of asthma. Especially evident is the deposition of collagen (especially type III) and fibronectin. Roche et al. [67] found no correlation between epithelial loss and collagen deposition. Since collagen type IV was absent from the sub-basement membrane deposit, they suggest that fibrogenesis is not related to epithelial damage and epithelial cell-derived products do not contribute. They suggest that the collagen deposition is more probably due to mast cell and eosinophil products. Roche et al. [67] did not consider the effect of epithelial cell-derived growth factors on collagen deposition by other cell types.

The cytokines IL- 1 and TGF- $\beta$ as well as plateletderived growth factor (PDGF) have a fibrogenic action [68], and are produced by epithelial cells. In cells with a high endogenous production of prostanoids, such as epithelial cells, the fibrogenic actions of IL-1 are only seen in the presence of cyclo-oxygenase inhibitors [68]. It is, therefore, unlikely that IL-1 has important fibrogenic actions in this system.

In addition to its effects on cytokine and prostanoid production, histamine stimulates fibronectin release in BEAS-2B cells [23]. Bovine bronchial epithelial cells produce fibronectin under basal conditions, where it acts as a chemoattractant for lung fibroblasts and epithelial cells $[69,70]$. This action may be important in regulating epithelial cell/fibroblast interactions in the airways during repair processes. TGF- $\beta$ may also have an important role in tissue repair. TGF- $\beta$ is also produced by bovine bronchial epithelial cells $[71,72]$, where the $\beta_{2}$ isoform predominates [71]. TGF- $\beta$ stimulates fibronectin gene expression and markedly increases fibronectin production in bovine bronchial epithelium [73]; it also stimulates fibronectin and collagen gene expression in fibroblasts [74].

Platelet-derived growth factor (PDGF) stimulates many of the processes important in tissue repair, including fibroblast chemotaxis and proliferation, smooth muscle cell proliferation, and collagen synthesis [75-77]. PDGF mRNA and/or protein have been demonstrated in lung epithelial cells in idiopathic pulmonary fibrosis [75], lung carcinoma [76], and in skin epithelial cells following injury [77]. There was no evidence of PDGF in normal epithelium. These findings suggest a modified production of PDGF in disease or injury. It is interesting to speculate whether PDGF is produced by asthmatic epithelial cells. This has not yet been examined.
STEWART et al. [78] have suggested that epithelial damage itself produces a rapid proliferation of epithelial cells. A role for epithelial cell-derived TGF- $\alpha$, epidermal growth factor (EGF) and endothelin-1 (ET-1) was also suggested. These mediators may also cause smooth muscle cell and fibroblast proliferation, and the increase in airways smooth muscle volume may contribute to BHR.

\section{Immunoregulation in the epithelium}

An area not yet considered is the potential of the airway epithelium to function in an antigen-presenting role. To trigger an allergic response, allergen must be "presented" to the immunocompetent T-lymphocytes. Whilst the characteristic antigen-presenting cells are the dendritic cells interdigitating through the epithelium, this latter cell type can assume an antigen-presenting role, especially in areas of inflammation [79]. Cytokine exposure, such as would occur in inflammation, can induce airway epithelial cells to express major histocompatibility complex (MHC) class II antigens and human leucocyte antigens (HLA) and the genes encoding for them [80]. Vignola et al. [61] have shown that HLADR expression is increased in asthmatic airway epithelium, and that the level of expression correlates with asthmatic symptoms and lung function. Thus, the airway epithelium is potentially important in antigen-presentation in the lung in asthma. More studies are required in this area.

It has recently been shown that immunoglobin $\mathrm{E}(\operatorname{IgE})$ can bind to pulmonary epithelial cells and suppresses $\beta$ adrenoceptor- and phosphodiesterase inhibitor-induced increases in cyclic adenosine monophosphate (cAMP) [81]. This, if it occurs in vivo, could have detrimental effects in asthma.

\section{Anti-inflammatory drug effects on the epithelium}

It is clear that asthma is an inflammatory disease, and it generally responds well to anti-inflammatory drugs. What is not yet clear is which is the important target cell and effect thereon for these drugs. LAITINEN et al. [82] have examined the effects of glucocorticosteroids on the histological appearance of bronchial biopsy samples from an asthmatic subject. During exacerbation of the asthma, marked mucosal inflammation occurred, with a reduction in the number of ciliated epithelial cells. This was accompanied by an increase in eosinophil number. These effects were reversed following 16 weeks of treatment with inhaled budesonide. This suggests an action in the airway mucosa.

The effects of anti-inflammatory drugs on epithelial cell activity in culture has also been examined.

\section{Glucocorticosteroids}

In human airway epithelial cells in culture, GMCSF release (basal and IL-1-induced) is inhibited by 
hydrocortisone, dexamethasone and budesonide [32, 33, 38]. GM-CSF mRNA was also reduced, suggesting inhibition of transcription [32]. Dexamethasone reduced GM-CSF release below basal levels [38]. In epithelial cells obtained from bronchial biopsies of asthmatic airways, hydrocortisone reduced GM-CSF, IL-6 and IL-8 release [37]. Glucocorticosteroid treatment reversed epithelial cell-dependent increases in eosinophil [33], but not neutrophil [39], survival and activation. In these cases, the granulocytes, not the epithelium, were treated with steroid. It would be interesting to determine the effects of glucocorticosteroid-treated epithelial cells on eosinophil and neutrophil survival. Whilst it is not possible to relate these in vitro observations directly to asthmatic inflammation, it is quite possible that the anti-inflammatory activity of steroids may result, at least in part, from inhibition of inflammatory actions of epithelial cellderived cytokines. This may be especially relevant to GM-CSF, where a reduction in its expression/production could lead to reduced eosinophil activity and survival.

Dexamethasone decreased TNF- $\alpha$-induced RANTES mRNA expression and RANTES production in A549 cells [50]. This could be expected to reduce eosinophil recruitment by the epithelium, and may be an important target for corticosteroid therapy in asthma [50].

Dexamethasone treatment of the NCI-H292 bronchial epithelial cell line reduced ICAM-1 expression and mRNA for ICAM-1, suggesting an action at the transcription level [62]. This finding was not supported by the lack of effect of beclomethasone on expression of ICAM-1 in asthmatic bronchial epithelium in vivo, even though inflammation was reduced and symptoms improved [60]. Thus, it would appear that steroid-induced reduction of ICAM-1 expression in vitro may not translate to an in vivo inhibition. Furthermore, it would also suggest that the anti-inflammatory effects of steroids are not dependent upon a reduction in adhesion molecule expression in the airway epithelium.

Table 1. - "Factors" expressed by or upgraded in the epithelium during inflammation or in asthma

\begin{tabular}{|c|c|c|}
\hline "Factor" & Upregulator & Possible consequence \\
\hline $\begin{array}{l}\text { Mediators } \\
\text { PGE }_{2}, \mathrm{PGF}_{2 \alpha}, \mathrm{PGI}_{2}, \mathrm{TxB}_{2} \\
\mathrm{LTB}_{4} \\
\mathrm{LTC}_{4}, \mathrm{LTD}_{4}, \mathrm{LTE}_{4} \\
\text { 15-HETE, HHT }\end{array}$ & $\mathrm{O}_{3}$ & $\begin{array}{l}\text { Bronchospasm, mucus secretion, } \\
\text { microvascular leakage, } \\
\text { chemotaxis }\end{array}$ \\
\hline $\begin{array}{l}\mathrm{PGE}_{2} \\
\text { LTC }_{4} \\
\text { 12-HETE, 15-HETE }\end{array}$ & $\mathrm{NO}_{2}$ & Vasodilation, bronchospasm \\
\hline Endothelin & Asthma & Bronchospasm, smooth muscle proliferation \\
\hline $\begin{array}{l}\text { Cytokines/chemokines } \\
\text { GM-CSF }\end{array}$ & $\begin{array}{l}\text { IL-1, histamine, } \mathrm{NO}_{2} \text {, inflammation, } \\
\text { asthma }\end{array}$ & $\begin{array}{l}\text { Prolong Eo/neut survival, increase Eo } \\
\text { activation }\end{array}$ \\
\hline IL-1 & TDI & Augment inflammation \\
\hline IL-6 & $\begin{array}{l}\text { IL- } 1 \text {, histamine, TNF- } \alpha \text {, TGF- } \beta \\
\text { asthma }\end{array}$ & Augment inflammation \\
\hline IL-8 & $\mathrm{RSV}, \mathrm{TNF}, \mathrm{IL}-1, \mathrm{NO}_{2}$ & Neut recruitment \\
\hline TNF- $\alpha$ & $\mathrm{NO}_{2}$ & Augment inflammation \\
\hline RANTES & IL-1, TNF & Eo, mono, basophil, T-cell recruitment \\
\hline MIP-2 & TNF & Inflammatory cell recruitment \\
\hline $\begin{array}{l}\text { Adhesion molecules } \\
\text { ICAM-1 }\end{array}$ & $\begin{array}{l}\text { IFN- } \gamma \text {, TNF- } \alpha, \text { IL-1, PIV } \\
\text { Antigen challenge (monkeys) } \\
\text { Asthma } \\
\text { Phorbol ester }\end{array}$ & Inflammatory cell (especially Eo) recruitment \\
\hline $\begin{array}{l}\text { Growth factors } \\
\text { Fibronectin }\end{array}$ & Histamine & Increased matrix formation \\
\hline PDGF (skin) & Injury & Fibroblast/smooth muscle proliferation \\
\hline $\begin{array}{l}\text { Immune factors } \\
\text { MHC-II }\end{array}$ & Inflammation & Increased antigen presentation \\
\hline HLA-DR & Asthma & Increased antigen presentation \\
\hline
\end{tabular}

Eo: eosinophil; GM-CSF: granulocyte-macrophage colony-stimulating factor; HETE: hydroxyeicosatetraenoic acid; HHT: hydroxyheptadecatrienoic acid; HLA-DR: human leucocyte antigen-DR; ICAM: intracellular adhesion molecule; IFN- $\gamma$ : interferon$\gamma$; IL: interleukin; LT: leukotriene; MHC-II: major histocompatibility complex II; MIP-2: macrophage inflammatory protein-2; mono: monocyte; neut: neutrophil; PDGF: platelet-derived growth factor; PG: prostaglandin; PIV: parainfluenza virus; RANTES: regulated on activation, normal T-cells, expressed and secreted; RSV: respiratory syncytial virus; $\mathrm{TxB}_{2}$ : thromboxane $\mathrm{B}_{2}$; TDI: toluene diisocyanate; TGF- $\beta$ : transforming growth factor- $\beta$; TNF- $\alpha$ : tumour necrosis factor- $\alpha$. 


\section{Nedocromil sodium}

Nedocromil sodium reduced IL-1-induced GM-CSF release by $40 \%$ in human bronchial epithelial cells in culture [40]. No effects were seen on basal release. Similarly, nedocromil sodium inhibited IL-1-induced IL-8 mRNA expression and IL-8 release but, as before, was without effect on basal release of IL-8 [45]. In each case, the effects were concentration-related.

It is conceivable that a reduction in cytokine release by the epithelium would reduce inflammatory cell chemotaxis, reduce their activation and prevent their survival, and this may account for some of the reported anti-inflammatory effects of nedocromil sodium.

\section{Phosphodiesterase inhibitors}

The role of isoenzyme-selective phosphodiesterase (PDE) inhibitors as anti-inflammatory agents is currently of great interest (for review see RAEBURN et al. [83]). Airway epithelial cells contain PDE types I-V [84]. Since PDE IV and, possibly, PDE V inhibitors have antiinflammatory actions on mononuclear cells and granulocytes in vitro, and on airways inflammation in vivo [83], they may also act at the epithelium.

\section{Conclusion}

Whilst the epithelium is normally regarded as a target for inflammatory mediators, it is clear from the information presented here that the epithelium is also capable of mounting and sustaining an inflammatory response. The factors produced by the epithelium or upregulated in these cells in inflammation and asthma are listed in table 1. Once targeted, the epithelium sets up a cycle of inflammatory changes which have profound effects. The mediators and cytokines produced and released and the adhesion molecules expressed, encourage the migration to, activation of, and survival of inflammatory cells (notably eosinophils) in the asthmatic airways. In addition, some of the mediators released stimulate smooth muscle cell and fibroblast proliferation characteristic of the airways remodelling seen in the asthmatic lung. Thus the damaged epithelium may have a central proinflammatory role. Drug treatment aimed at stabilizing the biochemical changes induced in the epithelium may be of tremendous benefit in clinical asthma.

\section{References}

1. Djukanovic R, Roche WR, Wilson JW, et al. Mucosal inflammation in asthma. Am Rev Respir Dis 1990; 142: 434-457.

2. Dunnill MS. The pathology of asthma with special reference to changes in the bronchial mucosa. J Clin Pathol 1960; 13: 27-33.

3. Dunnill MS, Massarella GR, Anderson JA. A comparison of the quantitave anatomy of the bronchi in normal subjects, in status asthmaticus, in chronic bronchitis and in emphysema. Thorax 1969; 24: 176-179.

4. Filley WV, Holley KE, Kephart GM, Gleich GJ. Identification by immunofluorescence of eosinophil granule major basic protein in lung tissues of patients with bronchial asthma. Lancet 1982; ii: 11-16.

5. Laitinen LA, Heino M, Laitinen A, Kava T, Haahtela T. Damage of the airway epithelium and bronchial reactivity in patients with asthma. Am Rev Respir Dis 1985; 131: 599-606.

6. Elia C, Bucca C, Rolla G, Scappaticci E, Cantino D. A freeze-fracture study of human bronchial epithelium in normal, bronchitic and asthmatic subjects. J Submicrosc Cytol Pathol 1988; 20: 509-517.

7. Beasley R, Roche WR, Roberts JA, Holgate ST. Cellular events in the bronchi in mild asthmatics. Am Rev Respir Dis 1989; 139: 806-817.

8. Jeffrey PK, Wardlaw AJ, Nelson FC, Collins JV, Kay AB. Bronchial biopsies in asthma: an ultrastructural, quantitative study and correlation with hyperreactivity. Am Rev Respir Dis 1989; 140: 1745-1753.

9. Lozewicz S, Wells C, Gomez E, et al. Morphological integrity of the bronchial epithelium in mild asthma. Thorax 1990; 45: 12-15.

10. Sanerkin NG, Evans DMD. The sputum in bronchial asthma: pathogonomic patterns. J Pathol Bact 1965; 89: 535-541.

11. Naylor B. The shedding of the mucosa of the bronchial tree in man. Thorax 1962; 17: 69-72.

12. Wardlaw AJ, Dunnette S, Gleich GJ, Collins JV, Kay AB. Eosinophils and mast cells in bronchoalveolar lavage in subjects with mild asthma: relationship to bronchial hyperreactivity. Am Rev Respir Dis 1988; 137: 62-69.

13. Fedan JS, Hay DWP, Farmer SG, Raeburn D. Epithelial cells: modulation of airway smooth muscle reactivity. In: Rodger IW, Barnes PJ, Thompson NC, eds. Asthma: Basic Mechanisms and Clinical Management. New York, Academic Press, 1988; pp. 143-162.

14. Raeburn D. Putative role of epithelial derived-factors in airway smooth muscle reactivity. Agents Actions 1990; 31(Suppl.): 259-274.

15. Goldie RG, Fernandes LB, Farmer SG, Hay DWP. Airway epithelium-derived inhibitory factor. Trends Pharmacol Sci 1990; 11: 67-70.

16. Holtzman MJ, Aizawa H, Nadel JA, Goetzl EJ. Selective generation of leukotriene $\mathrm{B}_{4}$ by tracheal epithelial cells from dogs. Biochem Biophys Res Commun 1983; 114: 1071-1076.

17. Hunter JA, Finkbeiner WE, Nadel JA, Goetzl EJ, Holtzman MJ. Predominant generation of 15-lipoxygenase metabolites of arachidonic acid by epithelial cells from human trachea. Proc Natl Acad Sci 1985; 82: 4633-4637.

18. Churchill L, Chilton FH, Resau JH, Bascom R, Hubbard WC, Proud D. Cyclo-oxygenase metabolism of endogenous arachidonic acid by cultured human tracheal epithelial cells. Am Rev Respir Dis 1989; 140: 449-459.

19. Eling TE, Danilowicz RM, Henke DC, Sivarajah K, Yankaskas JR, Boucher RC. Arachidonic acid metabolism by canine tracheal epithelial cells: product formation and relationship to chloride secretion. J Biol Chem 1986; 261: 12841-12849.

20. Robinson C, Campbell A, Herbert CA, Sapsford RJ, Devalia JL, Davies RJ. Calcium-dependent release of eicosanoids in human cultured bronchial epithelial cells. Br J Pharmacol 1990; 100: 471P.

21. Leikauf GD, Ueki IF, Widdicombe JH, Nadel JA. 
Alteration of chloride secretion across canine tracheal epithelium by lipoxygenase products of arachidonic acid. Am J Physiol 1986; 250: 47-53.

22. Salari H, Wong A. Generation of platelet-activating factor (PAF) by a human lung epithelial cell line. Eur J Pharmacol 1990; 175: 253-259.

23. Noah TL, Paradiso AM, Madden MC, McKInnon KP, Devlin RB. The response of a human bronchial cell line to histamine: intracellular calcium changes and extracellular release of inflammatory mediators. Am J Respir Cell Mol Biol 1991; 5: 484-492.

24. Masuda T, Suda Y, Shimura S, et al. Airway epithelial cells enhance eosinophil survival. Respiration 1992; 59: 238-242.

25. Leikauf GD, Driscoll KE, Wey HE. Ozone-induced augmentation of eicosanoid metabolism in epithelial cells from bovine trachea. Am Rev Respir Dis 1988; 137: 435-442.

26. Sapsford RJ, McCloskey DT, Devalia JL, Cundell DR, Davies RJ. Nitrogen dioxide $\left(\mathrm{NO}_{2}\right)$ : effects on human bronchial epithelial cell function in vitro. Thorax 1991; 46: 306P.

27. McKinnon KP, Madden MC, Noah TL, Devlin RB. In vitro ozone exposure increases release of arachidonic acid products from a human bronchial epithelial cell line. Toxicol Appl Pharmacol 1993; 118: 215-223.

28. Rozengurt N, Springall DR, Polak JM. Localization of endothelin-like immunoreactivity in airway epithelium of rats and mice. J Pathol 1990; 160: 5-8.

29. Rennick RE, Loesch A, Burnstock G. Endothelin, vasopressin, and substance P-like immunoreactivity in cultured and intact epithelium from rabbit trachea. Thorax 1992; 47: 1044-1049.

30. Springall DR, Howarth PH, Counihan H, Djukanovic R, Holgate ST, Polak JM. Endothelin immunoreactivity of airway epithelium in asthmatic patients. Lancet 1991; 337: 697-701.

31. Cluzel M, Lee TH. Cytokines. In: Rodger IW, Barnes PJ, Thompson NC, eds. Asthma: Basic Mechanisms and Clinical Management. New York, Academic Press, 1992; pp. 315-331.

32. Cox G, Ohtoshi T, Vancheri C, et al. Promotion of eosinophil survival by human bronchial epithelial cells and its modulation by steroids. Am J Respir Cell Mol Biol 1991; 4: 525-531.

33. Marini M, Soloperto M, Mezzetti M, Fasoli A, Mattoli S. Interleukin-1 binds to specific receptors on human bronchial epithelial cells and upregulates granulocyte/macrophage colony-stimulating factor synthesis and release. Am J Respir Cell Mol Biol 1991; 4: 519524.

34. Soloperto M, Mattoso VL, Fasoli A, Mattoli S. A bronchial epithelial cell-derived factor in asthma that promotes eosinophil activation and survival as GM-CSF. Am J Physiol 1991; 260: L530-538.

35. Ohtoshi T, Tsuda T, Vancheri C, et al. Human upper airway epithelial cell-derived granulocyte-macrophage colony-stimulating factor induces histamine-containing cell differentiation of human progenitor cells. Int Arch Allergy Appl Immunol 1991; 95: 376-384.

36. Ohtoshi T, Vancheri C, Cox G, et al. Monocyte-macrophage differentiation induced by human upper airway epithelial cells. Am J Respir Cell Mol Biol 1991; 4: 255263.

37. Marini M, Vittori E, Hollemborg J, Mattoli S. Expression of the potent inflammatory cytokines, granulocytemacrophage colony-stimulating factor and interleukin-6 and interleukin-8, in bronchial epithelial cells of patients with asthma. J Allergy Clin Immunol 1992; 89: 1001-1009.

38. Churchill L, Friedman B, Schleimer RP, Proud D. Production of granulocyte-macrophage colony-stimulating factor by cultured human tracheal epithelial cells. Immunology 1992; 75: 189-195.

39. Cox G, Gauldie J, Jordana M. Bronchial epithelial cellderived cytokines (G-CSF and GM-CSF) promote the survival of peripheral blood neutrophils in vitro. Am J Respir Cell Mol Biol 1992; 7: 507-513.

40. Marini M, Soloperto M, Zheng Y, Mezzetti M, Mattoli $\mathrm{S}$. Protective effect of nedocromil sodium on the IL-1induced release of GM-CSF from cultured human bronchial epithelial cells. Pulm Pharmacol 1992; 5: 61-65.

41. Kalb TH, Siden EJ, Marom ZM, Mayer L. Detection of interleukin 6 mRNA in human airway epithelial cells. Am Rev Respir Dis 1991; 143: A613.

42. Mattoli S, Miante S, Calabro F, Mezzetti M, Fasoli A, Allegra L. Bronchial epithelial cells exposed to cyanates potentiate activation and proliferation of T-cells. Am J Physiol 1990; 259: L320-327.

43. Tamaoki J, Yamawaki I, Takeyama K, Chiyotani A, Yamauchi F, Konno K. Interleukin-1, $\beta$-inhibits airway smooth muscle contraction via epithelium-dependent mechanism. Am J Respir Crit Care Med 1994; 149: 134-137.

44. Takizawa H, Ohtoshi T, Ohta K, et al. Interleukin 6/Bcell stimulatory factor-II is expressed and released by normal and transformed human bronchial epithelial cells. Biochem Biophys Res Commun 1992; 187: 596602 .

45. Vittori E, Sciacca F, Colotta F, Mantovani A, Mattoli S. Protective effect of nedocromil sodium on the interleukin1 -induced production of interleukin- 8 in human bronchial epithelial cells. J Allergy Clin Immunol 1992; 90: 76-84.

46. Becker S, Koren HS, Henke DC. Interleukin-8 expression in normal nasal epithelium and its modulation by infection with respiratory syncitial virus and cytokines tumor necrosis factor, interleukin-1, and interleukin-6. Am J Respir Cell Mol Biol 1993; 8: 20-27.

47. Devalia JL, Campbell AM, Sapsford RJ, et al. Effect of nitrogen dioxide on synthesis of inflammatory cytokines expressed by human bronchial epithelial cells. Am J Respir Cell Mol Biol 1993; 9: 271-278.

48. Chen H, Munakata M, Amishima M, et al. Gammainterferon modifies guinea-pig airway functions in vitro. Eur Respir J 1994; 7: 74-80.

49. McLean A. Regulation with RANTES. Lancet 1994; 343: 189-190.

50. Kwon OJ, Jose PJ, Robbins RA, Schall TJ, Williams TL, Barnes PJ. Dexamethasone inhibition of RANTES expression in cultured human lung epithelial cells. Am J Respir Crit Care Med 1994; 149: A944.

51. Driscoll KE, Hassenbein DG, Carter J, et al. Macrophage inflammatory proteins 1 and 2: expression by rat alveolar macrophages, fibroblasts and epithelial cells and in rat lung after mineral dust exposure. Am J Respir Cell Mol Biol 1993; 8: 311-318.

52. Albelda SM. Endothelial and epithelial cell adhesion molecules. Am J Respir Cell Mol Biol 1991; 4: 195-203.

53. Calderon E, Lockey RF. A possible role for adhesion molecules in asthma. J Allergy Clin Immunol 1992; 90: 852-865.

54. Tosi MF, Stark JM, Smith CW, Hamedani A, Gruenert DC, Infeld MD. Induction of ICAM-1 expression on human airway epithelial cells by inflammatory 
cytokines: effects on neutrophil-epithelial cell adhesion. Am J Respir Cell Mol Biol 1992; 7: 214-221.

55. Look DC, Rapp SR, Keller BT, Holtzman MJ. Selective induction of intercellular adhesion molecule-1 by interferongamma in human airway epithelial cells. Am J Physiol 1992; 263: L79-87.

56. Stark JM, Smith CW, Gruenert DC, Tosi MF. Neutrophil adhesion to parainfluenza virus-infected human airway epithelial cells: possible contributions of ICAM-1-dependent and ICAM-1-independent mechanisms. Chest 1992; 101 (Suppl.): 40S-41S.

57. Bloemen PGM, van den Tweel MC, Henricks PAJ, et al. Expression and modulation of adhesion molecules on human bronchial epithelial cells. Am J Respir Cell Mol Biol 1993; 9: 586-593.

58. Wegner CD, Gundel RH, Reilly P, Haynes N, Letts LG, Rothlein R. Intercellular adhesion molecule-1 (ICAM1) in the pathogenesis of asthma. Science 1990; 247: 456-459.

59. Wegner CD, Gundel RH, Rothlein R, Letts LG. Expression and probable roles of cell adhesion molecules in lung inflammation. Chest 1992; 101(Suppl.): 34S-39S.

60. Montefort $\mathrm{S}$, Roche WR, Howarth PH, et al. Intercellular adhesion molecule-1 (ICAM-1) and endothelial leucocyte adhesion molecule-1 (ELAM-1) expression in the bronchial mucosa of normal and asthmatic subjects. Eur Respir J 1992; 5: 815-823.

61. Vignola AM, Campbell AM, Chanez P, et al. HLA-DR and ICAM-1 expression on bronchial epithelial cells in asthma and chronic bronchitis. Am Rev Respir Dis 1993; 148: 689-694.

62. van de Stolpe A, Caldenhoven E, Raaijmakers JAM, van der Saag PT, Koenderman L. Glucocorticoid-mediated repression of intercellular adhesion molecule- 1 expression in human monocytic and bronchial epithelial cell lines. Am J Respir Cell Mol Biol 1993; 8: 340-347.

63. Ciprandi G, Buscaglia S, Pesce G, Villaggio B, Canonica GW. Allergic subjects express intercellular adhesion molecule-1 (ICAM-1 or CD54) on epithelial cells of conjunctiva after allergen challenge. J Allergy Clin Immunol 1993; 91: 783-792.

64. Wuthrich RP, Jenkins TA, Snyder TL. Regulation of cytokine-stimulated vascular cell adhesion molecule-1 expression in renal tubular epithelial cells. Transplantation 1993; 55: 172-177.

65. Robbins RA, Koyama S, Spurzem JR, et al. Modulation of neutrophil and mononuclear cell adherence to bronchial epithelial cells. Am J Respir Cell Mol Biol 1992; 7: 19-29.

66. Schroth MK, Shasby DM. Cytokine-mediated changes in PMN adherence to canine tracheal epithelial cells. Chest 1992; 101(Suppl.): 39S-40S.

67. Roche WR, Beasley R, Williams JH, Holgate ST. Subepithelial fibrosis in the bronchi of asthmatics. Lancet 1989; i: 520-524.

68. Kovacs EJ. Fibrogenic cytokines: the role of immune mediators in the development of scar tissue. Immunol Today 1991; 12: 17-23.

69. Shoji S, Rickard KA, Ertl RF, Robbins RA, Linder J, Rennard SI. Bronchial epithelial cells produce lung fibroblast chemotactic factor: fibronectin. Am J Respir Cell Mol Biol 1989; 1: 13-20.

70. Shoji S, Ertl RF, Linder J, Romberger DJ, Rennard SI.
Bronchial epithelial cells produce chemotactic activity for bronchial epithelial cells. Am J Respir Dis 1990; 141: 218-225.

71. Sacco O, Romberger D, Rizzino A, Beckmann JD, Rennard SI, Spurzem JR. Spontaneous production of transforming growth-factor- $\beta 2$ by primary cultures of bronchial epithelial cells: effects on cell behaviour in vitro. J Clin Invest 1992; 90: 1379-1385.

72. Beckmann JD, Illig M, Romberger D, Rennard SI. Induction of fibronectin gene expression by transforming growth-factor- $\beta 1$ is attenuated in bronchial epithelial cells by ADP-ribosyltransferase inhibitors. $J$ Cell Physiol 1992; 152: 274-280.

73. Romberger DJ, Beckmann JD, Claassen L, Ertl RF, Rennard SI. Modulation of fibronectin production of bovine bronchial epithelial cells by transforming growth factor- $\beta$. Am J Respir Cell Mol Biol 1992; 7: 149-155.

74. Ignotz RA, Massague J. Transforming growth factor- $\beta$ stimulates the expression of fibronectin and collagen and their incorporation into the extracellular matrix. $J$ Biol Chem 1986; 261: 4337-4345.

75. Antoniades HN, Bravo MA, Avila RE, et al. Plateletderived growth factor in idiopathic pulmonary fibrosis. J Clin Invest 1990; 86: 1055-1064.

76. Antoniades HN, Galanopoulos T, Neville-Golden J, O'Hara CJ. Malignant epithelial cells in primary human lung carcinomas co-express in vivo platelet-derived growth factor (PDGF) and PDGF receptor mRNAs and their protein products. Proc Natl Acad Sci 1992; 89: 39423946.

77. Antoniades HN, Galanopoulos T, Neville-Golden J, Kiritsy $\mathrm{CP}$, Lynch SE. Injury induces in vivo expression of platelet-derived growth factor (PDGF) and PDGF receptor mRNAs in skin epithelial cells and PDGF mRNA in connective tissue fibroblasts. Proc Natl Acad Sci 1991; 88: 565-569.

78. Stewart AG, Tomlinson PR, Wilson J. Airway wall remodelling in asthma: a novel target for the development of anti-asthma drugs. Trends Pharmacol Sci 1993; 14: 275-279.

79. Holt PG. Macrophage dendritic cell interaction in regulation of IgE response in asthma. Clin Exp Allergy 1993; 23: 4-6.

80. Davies RJ, Devalia JL. Epithelial cells. In: Rodger IW, Barnes PJ, Thompson NC, eds. Asthma: Basic Mechanisms and Clinical Management. New York, Academic Press, 1992; pp. 143-156.

81. Ali K, Calderon EG, Brooks SM, Coffey RG, Lockey $\mathrm{RF}$. The in vitro effect of immunoglobulin $\mathrm{E}$ (IgE) on cyclic AMP concentrations in A549 human pulmonary epithelial cells with or without beta-adrenergic stimulation. FASEB J 1993; 7: A146.

82. Laitinen LA, Laitinen A, Heino M, Haahtela T. Eosinophilic airway inflammation during exacerbation of asthma and its treatment with inhaled corticosteroid. Am Rev Respir Dis 1991; 143: 423-427.

83. Raeburn D, Souness JE, Tomkinson A, Karlsson J-A. Isozyme-selective cyclic nucleotide phosphodiesterase inhibitors: biochemistry, pharmacology and therapeutic potential in asthma. Prog Drug Res 1993; 40: 9-32.

84. Rousseau E, Gagnon J, Lugnier C. Soluble and particulate cyclic nucleotide phosphodiesterases characterized from airway epithelial cells. FASEB J 1993; 7: A146. 